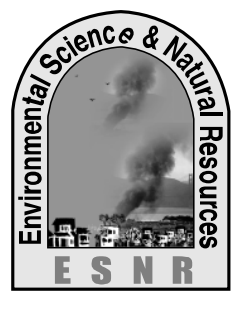

J. Environ. Sci. \& Natural Resources, 5(2): 129 - 136, 2012

ISSN 1999-7361

\title{
Farmers' Perception Regarding Climate Change and Crop Production, Especially for Wheat in Dinajpur District
}

\author{
J. A. Syeda ${ }^{1}$ and M. Nasser ${ }^{2}$ \\ ${ }^{1}$ Department of Statistics, Hajee Mohammad Danesh Science and Technology University, Dinajpur, Bangladesh \\ 2 Department of Statistics, University of Rajshahi, Rajshahi-6205, Bangladesh
}

\begin{abstract}
An attempt was made to depict the valuable experience of farmers about climate change, environment and agricultural production, particularly wheat by conducting an opinion survey among 50 years and above aged farmers and agricultural workers in selected mauzas of Dinajpur district. Three hundred thirteen (313) respondents were interviewed in the survey. All the respondents opined regarding climate change in Dinajpur district over time. All of them opined that crop land, crop cultivation and crop yield were affected due to climatic change and changing of climate might pose a big and devastating threat to the production of wheat. Besides, the three case studies were accomplished to explore new ideas about climate change and the behavior of nature and human culture. They had also similar types of experience about climate change.
\end{abstract}

Key words: Climate change, Fermers, Wheat

\section{Introduction}

Climate indicates the long term average weather conditions of a specific area of the earth while weather is the state of the atmosphere at a specific time. Temperature, humidity, precipitation, wind speed, atmospheric pressure, sunshine hour, cloudiness, soil temperature, soil moisture, evaporation, evapotranspiration, radiation, dew, fog etc. are the climatic parameters. Climate change means change of frequency and intensity pattern among the climatic factors such as precipitation, temperature, sunlight, wind etc. More precisely, the weather changes collectively make up the climate change. Agriculture, irrigated or rainfed, is inherently vulnerable to climatic hazards (Lenka, 1998). Global warming may affect agriculture by directly altering yields, changing water availability, or affecting soils (Anonymous, 1998). Food shortage can occur due to a sharp decline in production resulting from adverse climatic factors such as extended drought, floods and/or cyclones. Successive crop production failures intensify the shortages (Lenka, 1998). So, a clear understanding of climate and its impacts on crop is vital for their production. Wheat yield is much sensitive to climate variation and change. Bangladesh has a tropical climate (BBS, 2004) and wheat is considered as the second staple food of the common people in this country. Again, Dinajpur produces the highest amount of wheat in Bangladesh and the area under its cultivation in this district is also high scaled due to the pleasant climatic conditions. But in recent years, its cultivation has been decreasing here and after 2000, the trend also registered a decreasing trend. So, in this paper an attempt was made to assess the impact of climate change on wheat production by conducting the survey of farmers' opinion. There are two types of statistical data; quantitative and qualitative. Quantitative data are important to make any prediction, probabilistic statement, etc. Oppositely, qualitative ones are necessary to know farmers' perception about any problem for descriptive qualitative analysis. But most of the operation research works should use both for valid conclusions regarding set objectives of the problem. Quantitative and qualitative data are not substitute of each other but complementary. There are several methods of collection of qualitative data: (i) Focus group discussion, (ii) Unstructured interview, (iii) Participatory rural appraisal (iv) Rapid rural appraisal (iv) Case study etc. In this study, unstructured interview was made with farmers to get their perception. In this method, an interviewer can move or change the conversation freely in any direction of interest during the interview (Kumar, 2008). In this approach, there is a chance to talk directly with the respondents regarding their reactions, ideas and views about climate changes.

\section{Methodology}

In 1984, greater Dinajpur was divided into three new districts: Dinajpur, Panchagarh and Thakurgaon. There are 13 Upazilas in Dinajpur, 5 in Panchagarh and also 5 in Thakurgaon. These 23 Upazillas were ranked on the basis of average wheat production rate for the years 2002-2003, 2003-2004 and 2004-2005. The secondary data for 23 Upazilas were used for the purpose of ranking. The survey was conducted among the farmers of selected 6 mauzas: two mauzas from 
each of those 3 districts namely Chotachenggram and Lakshmipur from Hakimpur of Dinapur, Khudrabanshbari and Uttar Maheshpur from Ranishankail of Thakurgaon, and Sukhati and Fatehpur from Atwari of Panchagarh Districts. The two Mauzas from each of these districts were selected using the simple random sampling technique. Hakimpur was the highest while Atwari was the lowest yielding Upazilas, and Ranisankail was the middle in the rank. The targeted population (respondents) of the study were the 50 years and above aged farmers. The three hundred thirteen (313) farmers of the said age group in the selected mauzas were interviewed. For the data collection, one set of interview schedule was pre-tested and reviewed in the field with the targeted group in order to test the validity and suitability of the schedule and to ascertain the time length of the interview as well as sequence of questions of schedules. After analyses of the pre-test results, the schedule was modified, refreshed and edited in the light of the feedback received from the analyses and then was finalized for data collection.

\section{Results and Discussions}

The findings from the survey are presented in this episode under different captions.

\section{Demographic Status}

Out of selected 313 respondents, $22.4 \%$ (70) were from Hakimpur, $15.3 \%$ (48) from Ranisankail and 62.3\% (195) from Atwari. On the other hand, 99.4\% were male and the rest $0.6 \%$ was female.

\section{Opinion on Climate Change}

Hundred percent $(100 \%)$ respondents replied in the affirmative form "Yes". The respondents were also asked to state whether there was any change in climatic characteristics since 1970-1975 and 100\% of them also replied affirmatively.

Table 1. presents the changes in amount of rainfall, duration of rainy season, beginning of rainy season, and characteristics of Ashar and Srabon months in rainy season due to climate change. About 90\% respondents mentioned that quantity of rainfall decreased than before. Approximately 5\% claimed that it increased than before, only $1 \%$ stated that it was same as it was, while $4 \%$ mentioned that rainfall was irregular and it did not follow any regular trend. Almost $88 \%$ respondents affirmed that the duration of rainfall became shorter, more or less 5\% argued that it became longer, nearly $5 \%$ mentioned that the duration was irregular and about $3 \%$ reported that it remained as it was earlier. About $20 \%$ mentioned that rainy season started earlier than before, around 24\% pointed out that it started late than before. Almost half (48\%) opined that the starting period of rainy season was not regular and sometimes it started earlier and sometimes late, while around $6 \%$ mentioned that there was no change. Nearly, $88 \%$ claimed that Ashar became drier than before, nearly $4 \%$ expressed that it was same as before. However, $7 \%$ stated that the situation of dryness did not remain constant in all the years. Just about $91 \%$ mentioned that the intensity of rainfall was not as before, while only $5 \%$ cited that the intensity of rainfall was as before. Approximately $3 \%$ opined that the trend of the intensity of rainfall in Srabon was irregular.

Table 1. Changes in rainfall, duration of rainy season, beginning of rainy season, and characteristics of Ashar and Srabon moths in rainy season due to climate change

\begin{tabular}{|c|c|c|c|c|c|c|c|c|c|c|c|c|c|c|}
\hline \multicolumn{3}{|c|}{$\begin{array}{c}\text { Amount } \\
\text { of rain }(\mathrm{mm})\end{array}$} & \multicolumn{3}{|c|}{$\begin{array}{c}\text { Duration } \\
\text { of rainy season }\end{array}$} & \multicolumn{3}{|c|}{$\begin{array}{c}\text { Beginning } \\
\text { of rainy season }\end{array}$} & \multicolumn{3}{|c|}{$\begin{array}{c}\text { Characteristics } \\
\text { of Ashar }\end{array}$} & \multicolumn{3}{|c|}{$\begin{array}{c}\text { Characteristics } \\
\text { of Srabon }\end{array}$} \\
\hline & $\mathrm{F}^{*}$ & $\mathrm{P} * *$ & & $\mathrm{~F}$ & $\mathrm{P}$ & & $\mathrm{F}$ & $\mathrm{P}$ & & $\mathrm{F}$ & $\mathrm{P}$ & & $\mathrm{F}$ & $\mathrm{P}$ \\
\hline Reduced & 281 & 89.8 & Shorter & 274 & 87.5 & $\begin{array}{l}\text { Happen } \\
\text { early }\end{array}$ & 61 & 19.5 & $\begin{array}{l}\text { Drier } \\
\text { than } \\
\text { previous }\end{array}$ & 276 & 88.2 & $\begin{array}{l}\text { Rainfall } \\
\text { like } \\
\text { previous }\end{array}$ & 14 & 4.5 \\
\hline Increase & 15 & 4.8 & Longer & 15 & 4.8 & $\begin{array}{l}\text { Happen } \\
\text { later }\end{array}$ & 76 & 24.3 & $\begin{array}{l}\text { Rainy } \\
\text { like } \\
\text { previous }\end{array}$ & 11 & 3.5 & $\begin{array}{l}\text { Not rains } \\
\text { like } \\
\text { previous }\end{array}$ & 285 & 91.1 \\
\hline Unchanged & 3 & 1.0 & Irregular & 15 & 4.8 & Unchanged & 18 & 5.8 & Irregular & 22 & 7.0 & Irregular & 10 & 3.2 \\
\hline Irregular & 13 & 4.2 & Same & 9 & 2.9 & Irregular & 151 & 48.2 & Others & 4 & 1.3 & Others & 3 & 1.0 \\
\hline Others & 1 & .3 & Total & 313 & 100.0 & Others & 6 & 1.9 & Total & 313 & 100.0 & Unknown & 1 & .3 \\
\hline Total & 313 & 100.0 & - & - & - & Unknown & 1 & .3 & - & - & - & Total & 313 & 100.0 \\
\hline- & - & - & - & - & - & Total & 313 & 100.0 & - & - & - & - & - & - \\
\hline
\end{tabular}


Table 2. presents the changes of temperature in summer, intensity of norwester, soil conditions in Jaistha, feeling of heat in Boishakh and Jaistha due to climate change. Nearly $69 \%$ respondents mentioned that the level of temperature decreased in Summer, while about $23 \%$ gave opposite views and argued that it increased. On the other hand, $3 \%$ reported that there was no variation in the level of temperature but $4 \%$ claimed that the change did not follow any regular pattern. Almost $90 \%$ stated that they felt lower intensity of norwester's hit, while about $8 \%$ opined that they felt higher intensity of norwester hit and some respondents expressed other views. About $92 \%$ claimed in favor of not cracking of soil, $7 \%$ opined in favor of cracking of soil and $1 \%$ mentioned other views. About $72 \%$ opined that they experienced less heat in Boishakh and Joistha than before. Approximately $19 \%$ experienced more heat after climate change, about $6 \%$ felt the same as before and $3.5 \%$ felt no regular pattern.

Table 2. Changes of temperature in summer, intensity of norwester, soil conditions in Jaistha and feeling of heat in Boishakh and Jaistha due to climate change

\begin{tabular}{|c|c|c|c|c|c|c|c|c|c|c|c|}
\hline \multicolumn{3}{|c|}{$\begin{array}{c}\text { Temperature } \\
\text { in summer }\end{array}$} & \multicolumn{3}{|c|}{$\begin{array}{c}\text { Intensity } \\
\text { of norwester }\end{array}$} & \multicolumn{3}{|c|}{$\begin{array}{l}\text { Soil conditions } \\
\text { in Jaistha }\end{array}$} & \multicolumn{3}{|c|}{$\begin{array}{c}\text { Feeling of heat } \\
\text { in Boishakh and Jaistha }\end{array}$} \\
\hline & $\mathrm{F}^{*}$ & $\mathrm{P} * *$ & & $\mathrm{~F}$ & $\mathrm{P}$ & & $\mathrm{F}$ & $\mathrm{P}$ & & $\mathrm{F}$ & $\mathrm{P}$ \\
\hline Decreased & 215 & 68.7 & Lower & 280 & 89.5 & Soil becomes craked & 22 & 7.0 & Lower & 224 & 71.6 \\
\hline Increased & 72 & 23.0 & Higher & 24 & 7.7 & $\begin{array}{l}\text { Not craked like } \\
\text { previous }\end{array}$ & 288 & 92.0 & Higher & 59 & 18.8 \\
\hline Unchanged & 10 & 3.2 & Same & 4 & 1.3 & Irreguar & - & - & Same & 18 & 5.8 \\
\hline Irregular & 12 & 3.8 & Irregular & 5 & 1.5 & Others & 3 & 1.0 & Irregular & 11 & 3.5 \\
\hline Others & 3 & 1.0 & Total & 313 & 100.0 & Total & 313 & 100.0 & Others & 1 & 0.3 \\
\hline Unknown & 1 & 0.3 & - & - & - & - & - & - & Total & 313 & 100.0 \\
\hline Total & 313 & 100.0 & - & - & - & - & - & - & - & - & - \\
\hline
\end{tabular}

Table 3. presents the changes in the intensity of coldness, duration, starting period, intensity of fog and changes of characteristics in winter due to climate change. Almost $74 \%$ informed that the intensity of coldness in winter was less than before, $21 \%$ confirmed that it increased, $5 \%$ replied that the intensity was same as before and only $1 \%$ found that it was irregular; that means the intensity of coldness in winter did not follow any regular pattern. Approximately 50\% affirmed that the length of winter season become longer, $37 \%$ confirmed that it become shorter, I\% observed that it was same as it was and $3 \%$ replied that the change was irregular. About $11 \%$ reported that winter season started earlier, $27 \%$ cited that it started lately, $44 \%$ confirmed that it started in due time and $18 \%$ expressed that the starting of winter was irregular. Nearly $54 \%$ expressed that the intensity of fog was less than before, $35 \%$ pointed out that the intensity of fog in winter was more than previous, $6 \%$ revealed that the fog was same as before and $4 \%$ explained that it was irregular. More or less $36 \%$ revealed that sometimes they felt slight hot in winter, $32 \%$ mentioned that they felt extreme cold in winter, 24\% accounted actual rainfall in winter, 6\% argued that they observed no remarkable change in winter and $8 \%$ reported that they experienced other changes.

Table 3. Changes in the intensity of coldness, duration, starting period, intensity of fog and changes of characteristics in winter due to climate change

\begin{tabular}{|c|c|c|c|c|c|c|c|c|c|c|c|c|c|c|}
\hline \multicolumn{3}{|c|}{ Intensity of coldness } & \multicolumn{3}{|c|}{ Duration } & \multicolumn{3}{|c|}{ Starting period } & \multicolumn{3}{|c|}{ Intensity of fog } & \multicolumn{3}{|c|}{ Changes of characteristics } \\
\hline & $\mathrm{F}^{*}$ & $\mathrm{P}^{* *}$ & & $\mathrm{~F}$ & $\mathrm{P}$ & & $\mathrm{F}$ & $P$ & & $\mathrm{~F}$ & $\mathrm{P}$ & & $\mathrm{F}$ & $\mathrm{P}$ \\
\hline Lower & 227 & 72.5 & Shorter & 116 & 37.1 & Came early & 34 & 10.9 & Same & 19 & 6.1 & Few rainfall & 76 & 24.2 \\
\hline Higher & 66 & 21.1 & Longer & 157 & 50.2 & Came later & 83 & 26.5 & More & 108 & 34.5 & Few storm & 8 & 2.55 \\
\hline Unchanged & 17 & 5.4 & Same & 29 & 9.3 & Just time & 136 & 43.5 & Less & 169 & 54.0 & Extreme cold & 103 & 32.9 \\
\hline Irregular & 3 & 1.0 & Irregular & 10 & 3.2 & Irregular & 56 & 17.9 & Irregular & 13 & 4.2 & Light hot & 114 & 36.4 \\
\hline Total & 313 & 100.0 & Others & 1 & 0.3 & Others & 4 & 1.3 & Others & 4 & 1.3 & $\begin{array}{l}\text { Nothing } \\
\text { happened }\end{array}$ & 20 & 6.3 \\
\hline - & - & - & Total & 313 & 100.0 & Total & 313 & 100.0 & Total & 313 & 100.0 & Others & 26 & 8.3 \\
\hline
\end{tabular}


Table 4. presents the changes in the dew intensity in autumn. About $75 \%$ argued that dew decreased, $11 \%$ expressed that dew increased, $11 \%$ informed that dew was unchanged, about $2 \%$ reported that it was irregular. Approximately $51 \%$ expressed that white clouds were noted in the sky, $16.6 \%$ supported that moonlight was noted in the sky, $6 \%$ confirmed that rainfall occurred in autumn like in rainy season, $7 \%$ stated that it was same as before and $7 \%$ mentioned other comments.

Table 4. Changes in the dew intensity in autumn

\begin{tabular}{lcccccccc}
\hline \multicolumn{1}{c}{ Issues } & Decreased & Increased & $\begin{array}{c}\text { Same } \\
\text { as before }\end{array}$ & Irregular & $\begin{array}{c}\text { Not } \\
\text { happened }\end{array}$ & $\begin{array}{c}\text { Other } \\
\text { comments }\end{array}$ & Unknown & Total \\
\hline Frequency & 234 & 34 & 34 & 5 & 1 & 4 & 1 & 313 \\
Percent & 74.8 & 10.9 & 10.9 & 1.6 & 0.3 & 1.3 & 0.3 & 100 \\
\hline
\end{tabular}

Table 5. presents the changes in characteristics of autumn and spring. Nearly $97 \%$ respondents confirmed that strong wind-speed in Choitra was not observed like before, $92 \%$ reported that they felt cold at night of Choitra, about $84 \%$ claimed that the chirping of cuckoo was very rare in the spring, $0.6 \%$ argued that the spring was same as before and about $4 \%$ expressed other comments about the spring.

Table 5. Changes in the characteristics of autumn and spring

\begin{tabular}{lrrlrr|}
\hline Changes in autumn & $\mathrm{F}^{*}$ & $\mathrm{P}^{* *}$ & Changes in spring & $\mathrm{F}$ \\
\hline Rainfall like rainy season & 19 & 6.1 & Feel cold at night & 288 & 92 \\
Moonlight & 52 & 16.6 & No existence of wind wave & 304 & 97.1 \\
Same as before & 21 & 6.7 & Lower chirping of cuckoo & 262 & 83.7 \\
White cloud in sky & 160 & 51.1 & Same as before & 2 & 0.6 \\
Others & 22 & 7.0 & Others & 13 & 4.2 \\
\hline
\end{tabular}

About $100 \%$ respondents replied that they were affected. When the respondents were asked about the type of impact due to change in climate, nearly $99 \%$ informed that water shortage became a great problem for wheat cultivation as it was not available at the proper time.

\section{Impacts of climate change on the environment}

Table 6. presents the impacts of climate change on the environment. More or less $90 \%$ respondents mentioned that ponds/canals/bills got dry due to climate change, approximately $93 \%$ reported that seasons played different roles than before, almost $83 \%$ reported that the incidence of drought was more frequent than before, nearly $53 \%$ claimed that the flood was more frequent than before, about $14 \%$ mentioned that the storm also occurred more than before. On the other hand, $86 \%$ declared that the intensity of storm was less than before. Around 34\% cited that agricultural production was hampered due to climate change and $5 \%$ noted other impacts.

Table 6. Impacts of climate change on environment

\begin{tabular}{lccccccc}
\hline \multicolumn{1}{c}{ Issues } & $\begin{array}{c}\text { Dryness } \\
\text { of ponds/ } \\
\text { canals/bills }\end{array}$ & $\begin{array}{c}\text { Season } \\
\text { became } \\
\text { different }\end{array}$ & $\begin{array}{c}\text { More } \\
\text { droughts }\end{array}$ & $\begin{array}{c}\text { More } \\
\text { floods }\end{array}$ & $\begin{array}{c}\text { More } \\
\text { storms }\end{array}$ & $\begin{array}{c}\text { Hampered } \\
\text { agricultural } \\
\text { production }\end{array}$ & $\begin{array}{c}\text { Other } \\
\text { impacts }\end{array}$ \\
\hline Frequency & 281 & 291 & 259 & 166 & 45 & 107 & 14 \\
Percent & 89.8 & 93.0 & 82.7 & 53.0 & 14.1 & 34.2 & 4.5 \\
\hline
\end{tabular}

Impacts of climate change on the agricultural sector Table 7. presents the nature of impacts on crop land and crop production. Around 99\% respondents reported that water was inadequate for cultivation. Approximately $97 \%$ informed that irrigation requirement was more frequent for crop cultivation, 
$89 \%$ pointed out that wetness of cropland decreased, $95 \%$ declared that the utilization of cropland was changed, $32 \%$ reported that the fertility of cropland became reduced, $24 \%$ mentioned that crop cultivation was not possible according to crop calendar, $25 \%$ stated that intensive cultivation of crop was not possible, $95 \%$ cited that types of crop cultivation was changed, $24 \%$ opined that yield decreased and $6 \%$ of the respondents opined other views.

Table 7. Nature of impacts on crop land and cultivation

\begin{tabular}{lcc}
\hline Issues & Frequency & Percent \\
\hline Not enough water for cultivation & 309 & 98.7 \\
Extra irrigation needed for cultivation & 304 & 97.1 \\
Decreased wetness of cropland & 279 & 89.1 \\
Changing use of cropland & 297 & 94.9 \\
Decreased productivity of cropland & 101 & 32.3 \\
Not cultivation as per crop calendar & 75 & 24.0 \\
Not intensively cultivated & 78 & 24.9 \\
Not those kinds of crops grow as before & 297 & 94.9 \\
Decreased the yield & 76 & 24.3 \\
Other comments on cropland \& production & 18 & 5.8 \\
\hline
\end{tabular}

Table 8. presents the impacts of climate change on some agricultural crops. About $65 \%$ respondents reported about Aus, 13\% confirmed about Aman, $64 \%$ reported about Boro, $27 \%$ stated about wheat, nearly $3 \%$ pointed out about sugarcane, about $88 \%$ declared about potato, $4 \%$ expressed about maize, $22 \%$ reported about Rabicrop and about $2 \%$ referred about other crops.

Table 8. Impact of climate change on selected agricultural crops

\begin{tabular}{ccccccccccc}
\hline Issues & Aus & Amon & Boro & Wheat & Sugarcane & Potato & Maize & Rabicrop & Other crops \\
\hline Frequency & 202 & 42 & 85 & 103 & 8 & 275 & 11 & 70 \\
Percentage & 64.5 & 13.4 & 27.2 & 32.9 & 2.6 & 87.9 & 3.5 & 22.4 & 1.9 & \\
\hline
\end{tabular}

Table 9. presents the impacts of climate change on wheat cultivation. More or less $84 \%$ respondents reported that wheat production decreased, $11.8 \%$ mentioned that it increased and $1 \%$ referred that it was unchanged. About $89 \%$ respondents claimed that it increased, $5 \%$ affirmed that it decreased, $1 \%$ argued that it was unchanged and $6 \%$ expressed other views. About $76 \%$ respondents affirmed that irrigation requirement increased on wheat field, $9 \%$

\section{Impacts of Climate Change on Wheat}

Table 9. Impacts of climate change on wheat cultivation

\begin{tabular}{|c|c|c|c|c|c|c|c|c|c|c|c|c|c|c|}
\hline Production & $\mathrm{F}^{*}$ & $\mathrm{P} * *$ & Pest & $\mathrm{F}$ & $\mathrm{P}$ & Irrigation & $\mathrm{F}$ & $\mathrm{P}$ & Sowing time & $\mathrm{F}$ & $\mathrm{P}$ & Area & $\mathrm{F}$ & $\mathrm{P}$ \\
\hline Decreased & 264 & 84.3 & Decreased & 14 & 4.5 & More & 237 & 75.7 & Changing & 90 & 28.8 & Decreased & 292 & 93.3 \\
\hline Increased & 37 & 11.8 & Increased & 278 & 88.8 & Less & 29 & 9.3 & Unchanged & 212 & 67.7 & Increased & 9 & 2.9 \\
\hline Unchanged & 3 & 1.0 & Unchanged & 3 & 1.0 & Same & 38 & 12.1 & Others & 10 & 3.2 & Unchanged & 5 & 1.6 \\
\hline Others & 9 & 2.9 & Others & 18 & 5.8 & Others & 9 & 2.9 & Unknown & 1 & .3 & Irrigular & 6 & 1.9 \\
\hline Total & 313 & 100.0 & Total & 313 & 100.0 & Total & 313 & 100.0 & Total & 313 & 100.0 & Unknown & 1 & .3 \\
\hline- & - & - & - & - & - & - & - & - & - & - & - & Total & 313 & 100.0 \\
\hline
\end{tabular}

confirmed that it decreased, $12 \%$ pointed out that it was unchanged and about 3\% expressed other views. Approximately $29 \%$ pointed that it was changed and $3 \%$ expressed other comments. More or less $94 \%$ respondents expressed that the land under wheat production decreased, nearly 3\% acknowledged that it increased while $2 \%$ expressed other views.

$$
\mathrm{F}^{*}=\text { Frequency, } \mathrm{P}^{* *}=\text { Percent }
$$


Table 10. presents the adverse impacts of climate change on wheat production. More or less $95 \%$ respondents claimed that the sowing of seeds got delay due to change in duration of rainy season, about $40 \%$ reported that the intensity of disease on wheat field increased due to thick fog and lack of sunlight, around $50 \%$ respondents supported that unfilled wheat grains increased due to wetness of soil, due to lowering of ground water tabel and due to change of temperature, nearly $85 \%$ agreed about the problem of threshing attributed to excessive rainfall in harvesting period and approximately 5\% expressed other comments about the adverse impacts of climate change on wheat cultivation.

Table 10. Adverse impacts of climate change on wheat production

\begin{tabular}{lcc}
\hline Issues & Frequency Percent \\
\hline Delayed reaping and sowing of wheat due to change in rainy season & 296 & 94.6 \\
Disease infection in wheat field due to thick fog and lack of adequate sunlight & 126 & 40.3 \\
Loss of yield due to wetness of soil, lowering of water tabel and change in temperature & 156 & 49.8 \\
Problem due to excessive rainfall after threshing of wheat & 265 & 84.7 \\
Other comments on damage in wheat production & 15 & 4.8 \\
\hline
\end{tabular}

Table 11. presents the more influencing factors of climate change on wheat production. Approximately $66 \%$ respondents identified that change of temperature was affecting wheat production, $51 \%$ reported that change in rainfall was responsible for that. Change in fog was identified by $13 \%$ respondents. Change in intensity of storm and sunlight was identified by 2 and $2 \%$, respectively. Other elements were accredited by $18 \%$ of the total respondents.

Table 11. More influencing factors of climate change on wheat production

\begin{tabular}{ccccccc}
\hline Issues & $\begin{array}{c}\text { Changes } \\
\text { in temperature }\end{array}$ & $\begin{array}{c}\text { Changes } \\
\text { in rainfall }\end{array}$ & $\begin{array}{c}\text { Changes } \\
\text { in fog }\end{array}$ & $\begin{array}{c}\text { Changes } \\
\text { in storm }\end{array}$ & $\begin{array}{c}\text { Changes } \\
\text { in sunlight }\end{array}$ & $\begin{array}{c}\text { Other } \\
\text { comments }\end{array}$ \\
\hline Frequency & 204 & 159 & 40 & 5 & 5 & 57 \\
Percent & 65.2 & 50.8 & 12.8 & 1.6 & 1.6 & 18.2 \\
\hline
\end{tabular}

Table 12. presents the future of wheat production in Dinajpur. Nearly $88 \%$ farmers mentioned that the future of wheat production was under threat while about $6 \%$ expressed that the future was bright and another $6 \%$ approved other views.

Table 12. Future of wheat production in Dinajpur due to climate change

\begin{tabular}{cccccc}
\hline Issues & $\begin{array}{c}\text { Under } \\
\text { threat }\end{array}$ & Brighter & Others & Unknown & $\begin{array}{c}\text { Total } \\
\text { respondents }\end{array}$ \\
\hline Frequency & 274 & 19 & 18 & 2 & 313 \\
Percent & 87.5 & 6.1 & 5.8 & 0.6 & 100.0 \\
\hline
\end{tabular}

\section{Case Studies}

During the collection of the quantitative information from the selected 313 respondents, three case studies were made with three farmers in order to explore new ideas and issues regarding climate, life, culture etc. where little theory was available and measurement was not clear (Islam, 2008). The following 3 illustrative farmers were selected for the purpose.

(a) The case of Md. Akram Khan, an old man of age
100+, was an inhabitant of the Mauza Chotachenggram of Hakimpur. He observed no drops of rainfall in Choitra in the previous periods and also mentioned that Choitra of that time was as like as the firing ulka. Very hot and the strongest windy days were experienced in Choitra when a lot of green mangos in the trees and cuckoo birds were also found. Moreover, the green leaves of trees had fallen down with the shocking and pressure of wind and the cattle ate those. Recalling his early age, he uttered a proverb 
about Mango "Maghe mul, Falgune guti, Chotre katikuti, Boishakhe ati, Joishthe chusi'. Then soil cracked creating big gaps in the field in Joistha and a big portion of the cracked soil was found on the spade at a time in his boyhood. In the previous rainy season, immense black and dark clouds gathered on the northwest corner and sound ' $g u r$ gur'. People feared and a very big ear bursting drops of rainfall and a very high speedy man turning wind flow they experienced. Sometimes, that type of rainfall scattered everything and men turned themmselves in the field and people took shelter in the mosque for safety leaving their house to escape from that excessive disrupting rainfall. In Bhadro and Aswin immense dew were observed and in Aswin and Kartik he experienced rainfall with wind called "Satah" and about that he auttured the proverb "Sonir satah sat din, budher satah tin din, ar joto satah hobe din ka din". He never experienced winter rainfall and fog in the early age but opposite scenario was being observed at present according to him.

(b) Mr. Ummedul Islam, Mauza Durra, Upazilla Hakimpur, claimed that cultivation of Boro was the most vital factor for decreased wheat cultivation where the drainage system for irrigation badly affected wheat lands by water. Besides, electricity shortage for irrigation, necessity of excessive insecticide, requirement of excess labor were also responsible for decreased wheat cultivation. He mentioned that yield of HYV Boro was 50-60maunds while wheat yielded only 12-21maunds. Further he expressed that planting of Boro continued from 15 Poush or end of Poush to 15 Magh. He also commented that if they could complete every process from all sides and sowing was done in proper time in plain fallow land yet wheat was not possible as the previous time (20 years ago). In the early time, 15 Kartik experienced winter and it continued upto 15 Falgun while at present that started from 15 Agrahayan and continued till the end of Choitra and that was not possible in the previous period, according to him. "Jodi Magher mogore hoy ban, tahole ale tikore hoy dhan" that is, the rainfall on the 1st week of Magh was very fruitful for growing rice and that rainfall was absent in present days. Fruits get damaged if the rainfall came at the first, middle or last stage of Falgun. When the rainfall came late it caused damage to buds of mango, drumstick, litchi, jackfruit etc. Wet soil, the outcome of cultivation of Boro, caused harm to the production of wheat because it needs dry soil. Cultivation of Boro was done through irrigation and water from the drains has a tendency to flow towards the lands where wheat was cultivated. That flow of water caused death to the young wheat plants. So, cultivation of wheat in those areas had been completely impossible. The rainfall shifted in the first, middle or in the last Falgun that caused the fruit damage. For example, he further mentioned about the fallen and damaged buds of mango, drumstick, litchi, jackfruit etc. He thought that droughtless situation was an artificial problem occurred due to cultivation of Boro in whole Bangladesh. According to him, norwester came from the corner of Isan but at present it was not found regularly and its presence was very scanty. Katari (continuous rainfall for some days) was observed in the later part of Kartik to the first of Agrahayan but that was not regular at present.

(c) Md. Insan Ali, an inhabitant of the Mauza Chotachenggram of Hakimpur Upazila, claimed that the area under wheat cultivation decreased due to climate change. He opined that they were not getting enough cold for wheat sowing. He also commented that winter came late at present. At the present time, it started in Magh but it started in the month of Agrahayan in the previous days.

\section{Conclusions}

Hundred percent respondents opined in favor of climate change in Dinajpur and $90 \%$ interviewees mentioned that the amount of rainfall in rainy season became insufficient than it was before. Coldness in winter became low than before as was opined by $73 \%$ and the temperature in summer fallen than before as was experienced by $69 \%$. In autumn, dew was not noted as before which was the opinion of $75 \%$. Spring did not behave as earlier. Cold affected people at night in Choitra and 92\% felt like that. Stormy and dusty wind did not blow as before and $97 \%$ opined it. Cuckoo was not found and sometimes remained silent and that was the opinion of $84 \%$ respondents. The changing behavior of climate severely affected the crop, productive land and total process of production as a whole and that was the response of about $100 \%$ interviewees. Sometimes winter brings unusual warmness and that was the opinion of $36 \%$. Due to behavior of climate change wheat production suffered a lot and that was the response of $84 \%$ respondents. Change in temperature affected the production of wheat greatly- that was the opinion of $65 \%$ and they claimed that to be the most potential reason. Changing of climate might pose a big and devastating threat to the production of wheat. $88 \%$ were in fear, lest the cultivation of wheat in future might be threatened. 


\section{References}

BBS. 2004. Compendium of Environment Statistics of Bangladesh 2004, Bangladesh Bureau of Statistics, Dhaka, Bangladesh.

Islam, N. 2008. An Introduction to Research Methodology (A Handbook for Business and Health Research), Mullik and Brothers, Dhaka.

Kumar, S. 2008. Methods for Community Participation: A Guide for Practitioner. India.
Lenka, D. 1998. Climate Weather and Crops in India, 23 Daryagang, New Delhi-110002. 5 p.

Anonymous. 1998. Measuring the Impact of Climatic Change of Indian Agriculture, The International Bank for Reconstruction and Development/The World Bank, World Bank Technical Paper No. 402, Washington D.C. 20433, USA. 10 p. 